\title{
Adhesive microflora on stainless steel coupons in seafood processing plant
}

\author{
Bui Thi Quynh Hoa ${ }^{1}$, Warapa Mahakarnchanakul ${ }^{1, ~ *, ~ T a n a b o o n ~ S a j j a a n a n t a k u l, ~}$ \\ Vichien Kitpreechavanich ${ }^{2}$ \\ ${ }^{1}$ Department of Food Science and Technology, Agro-Industry Faculty, Kasesart University, Bangkok 10900, Thailand \\ ${ }^{2}$ Department of Microbiology, Faculty of Science, Kasesart University, Bangkok 10900, Thailand
}

\section{Email address:}

fagiwpm@ku.ac.th (W. Mahakarnchanakul), btqhoa71@gmail.com (B. T. Q. Hoa)

\section{To cite this article:}

Bui Thi Quynh Hoa, Warapa Mahakarnchanakul, Tanaboon Sajjaanantakul, Vichien Kitpreechavanich. Adhesive Microflora on Stainless Steel Coupons in Seafood Processing Plant. Journal of Food and Nutrition Sciences. Special Issue: Food Processing and Food Quality. Vol. 3, No. 1-2, 2015, pp. 28-32. doi: 10.11648/j.jfns.s.2015030102.15

\begin{abstract}
Adhering microflora profile is essential for the development and design of cleaning and sanitizing procedures, which is a part of the HACCP system. The profile provides a complete view of the target microorganisms that can potentially contaminate food products. The aim of this study is, therefore, focused on examination of microbial population adhered to the equipment surfaces at seafood processing plant. Adhering microflora was evaluated by installing the stainless steel coupons on the surface of equipment. Seventy stainless steel coupons were attached on 7 different locations at seafood processing plant and then fourteen coupons were collected at 1,2,3,5 and 9 weeks interval. The population of bacteria adhered on samples were enumerated using swab test and spread plate method on different selective microbiological media. The total viable count and Pseudomonas spp. population found on the stainless steel coupons were ranged from $10^{1}$ to $10^{6} \mathrm{cfu} / \mathrm{cm}^{2}$. The results also indicated that mature biofilm might form at some locations after three weeks. After 5 weeks, the highest viable bacterial population $\left(10^{6} \mathrm{cfu} / \mathrm{cm}^{2}\right)$ was observed on the stainless steel coupons attached in the trolley used for carrying the soup. These finding supported that the appropriate cleaning and sanitizing procedure should be strictly applied to assure safety in food processing plant.
\end{abstract}

Keywords: Biofilm Formation, Microflora, Stainless Steel Coupon, Seafood Processing

\section{Introduction}

A major goal for the food processing industry is production of good food both in terms of quality and safety of the consumer $[1,2]$. To reach this goal, microorganisms associated with food spoilage and food borne disease should be controlled [1]. During processing and preservation techniques, a part of them are eliminated. However, the efficient cleaning and disinfecting procedures are the main requirements because many food pathogenic and spoilage bacteria are able to attach to food contacting surfaces $[3,4,5]$. Moreover, they might still remain viable even after cleaning and disinfection which might lead to food contamination [2, 4, 6-8]. Among many reasons causing food contamination, microbial biofilm is important. A biofilm can be broadly defined as a microbiologically derived sessile community characterized by cells that are attached to a substratum or interface or to each other. Biofilms are embedded in a matrix of extracellular polymeric substances (EPS) that they have produced $[9,10]$. In real food processing environments, biofilm communities are inhabited by numerous different species. Mixed-species biofilms are usually more stable than mono-species biofilms. Cell-to-cell interactions have been demonstrated to play a key role in biofilm formation, biofilm structure, as well as in the resistance of biofilm community members against antimicrobial treatments [4, 11-13]. That is the reason why cells in biofilm are significantly resistant to sanitizers compared with the same cells being planktonic [4, $8,14]$. They also enhance the capacity to survive under stresses conditions that are commonly encountered within food processing $[3,15,16]$.

Many studies have been attempted to investigate the behavior of mono-species biofilms, both of spoilage bacteria and specific pathogens such as Pseudomonas spp. and Listeria monocytogenes; Salmonella spp.; Staphylococcus spp. [11, 17-21]. However, limited research has been 
published related to the microbiology of food processing surfaces even though microbial contamination in the processing environment is an important parameter. The microorganisms present are likely a mixture of many species $[4,22]$ and some of these microorganisms produce exopolymers that can facilitate the retention of pathogenic microorganism [5]. Understanding the characteristics of adhered microflora on food processing equipment would provide valuable information in designing the cleaning and disinfecting procedures.

Therefore, the objective of this study was to investigate the biofilm formation in seafood processing plant by the population of microflora adhered on stainless steel coupons at different interval of 9 week study. The results of this study will help in understanding the time required for biofilmformation in food processing plant; which will consequently help in improving the effectiveness of the cleaning and disinfecting procedures.

\section{Material and Methods}

\subsection{Processing Plant and Product Manufacturing}

Samples were taken from the surface equipment at a high care area in a seafood processing plant which produced ready to eat food. Experiment was carried out during October 2013 to April 2014.

In the food processing plant, a cooker first cooked and then the content was transferred through blue conveyor for cooling down. Once cooled, the products were passed through white conveyer to a container for adding herbs. Products were subsequently frozen before adding soup and frozen again. After that, they were transferred to packaging section.

At the end of each production day, a complete cleaning and disinfecting procedure was carried out. Cleaning was performed using low-pressure and foam cleaners. Alkaline detergent, superp foam was used as cleaning agent, and then spectrum (Quaternary ammonium compounds) was used for disinfecting.

\subsection{Stainless Steel Coupons Preparation and Installation}

Stainless steel (type 304, no. 2B finish), which is extensively used in the manufacturing of food processing equipment [23], was used in this study. Based on the result from preliminary experiment, seven locations (Fig.1) in the food processing plant were determined for installing stainless steel coupons. Before installation, stainless steel (SS) coupons $(2 \times 5 \mathrm{~cm})$ were soaked overnight in commercial detergent solution, degreased with $70 \%$ ethanol, thoroughly rinsed with tap water and then with distilled water, air-dried and sterilized by autoclaving for $15 \mathrm{~min}$ at $121^{\circ} \mathrm{C}[23,24]$. After that, sterilized SS coupons were transferred to the food processing plant (FPP). At FPP, SS coupons were attached at 7 different locations near food contact surfaces by rubber silicone sealant (SP-N192, Sparko, Thailand) [25]. Seventy SS coupons samples were kept in the FPP for 1 week, 2 weeks, 3 weeks, 5 weeks and 9 weeks. The sanitary procedures include fresh-water rinsing every 3 hours, and completed clean in the end of working day consist of water rinsing, cleaning with alkaline detergent and disinfecting with quaternary ammonium compounds (QACs).

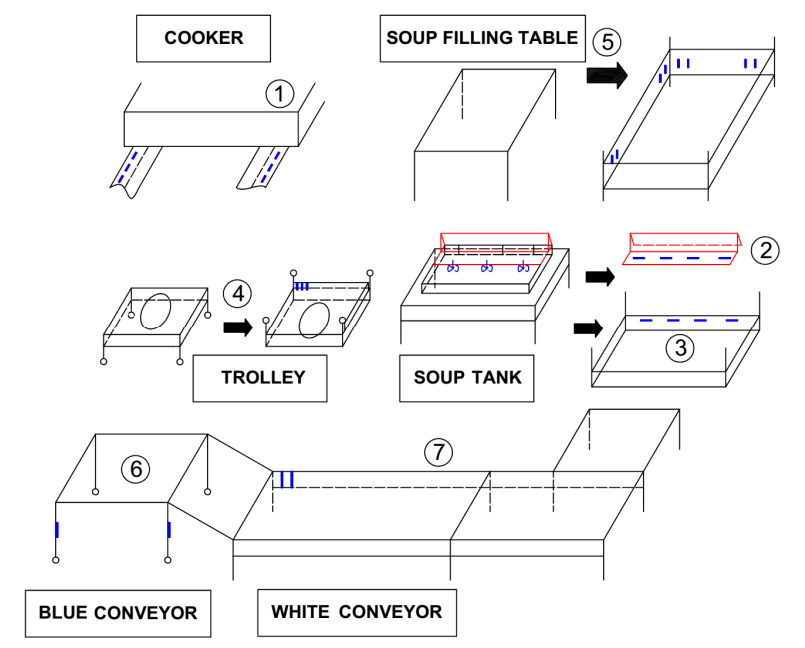

Fig. 1. Diagram of locations where stainless steel coupons $(\rightarrow)$ were installed on the equipment at food processing plant.

\subsection{Microbiological Analysis}

At each sampling period, fourteen SS coupons were aseptically detached and placed into plastic petri dishes, sealed and placed in cooling box, and then transported to the laboratory. Samples for microbiological analysis were taken from the entire surface of each coupon twice with cotton swab. Before swab test, SS coupon was rinsed twice with 10 $\mathrm{ml}$ distilled water, then swabbed thoroughly on the side without glue; after that the swab heads were broken off into a glass tube. The tube containing the cotton swab blended with $10 \mathrm{ml}$ of sterile physiological $(0.85 \%)$ salt water with $0.1 \%$ peptone for 60s [1]. Serial dilutions were prepared for each sample and spread duplicate onto Tryptic soy agar (TSA) (Difco) and Citrimide agar (Difco). The plates of TSA and Citrimide agar were incubated at $37^{\circ} \mathrm{C}$ for 1 day for testing total viable count and Pseudomonas spp.

\section{Results and Discussion}

The populations of total viable count (TVC) and Pseudomonas spp. at different sampling locations and at different sampling times are presented in Table 1 and Table 2.

It is observed that microbial adhesion appeared in many inspected locations and the microbial population ranged from $10^{1}-10^{6} \mathrm{cfu} / \mathrm{cm}^{2}$. The similar experimental findings was also reported by Birna et al. [26] at shrimp factory, where bacteria population in the range of 10 to $10^{4} \mathrm{cfu} / \mathrm{cm}^{2}$ were obtained at two sampling times, 2 months and 4 months. The result indicated that it might be unlikely to develop large biofilm structures with multilayer bacteria in food processing environments, for examples above $10^{8} \mathrm{cfu} / \mathrm{cm}^{2}$, because the regular use of sanitizer and low temperature in working area 
limit the extensive biofilm formation [26]. Similarly, another research in ice-cream plant reported that SS coupons placed near food contact surface did not contain high levels of microorganisms in short time; the highest number was $6.5 \times$ $10^{3} \mathrm{cfu} / \mathrm{cm}^{2}$ after $8 \mathrm{~h}$ at conveyor belt [27]. However, these adherent microorganisms could still contribute to the contamination of food products. Increasing sampling time from 1 to 5 weeks increased the number of adhered microorganisms on SS coupons; the highest bacteria population was detected at trolley $\left(8.2 \times 10^{6} \mathrm{cfu} / \mathrm{cm}^{2}\right)$. It was observed that biofilm formed after three weeks at some locations such as guide of cooker, trolley, soup filling table and the bottom of soup tank with bacterial population ranged from $2.3 \times 10^{5}$ to $4.0 \times 10^{5} \mathrm{cfu} / \mathrm{cm}^{2}$; indicating that the cleaning procedure was improper. In addition, regular daily cleaning and disinfection procedures was carried out, sampling and analysis over long period (from 1 to 9 weeks) demonstrated that mature biofilm could be formed after 3 weeks, especially in locations where high nutrient was present that was necessary for the growth of organisms. Biofilm formation on equipment surfaces increases the biotransfer potential that can be described as the ability of any microorganisms present on equipment surfaces both before and after the cleaning procedures to contaminate a product during processing.

Table 1. Population of adhered microflora enumerated as Total viable count $\left(\mathrm{CFU} / \mathrm{cm}^{2}\right)$ at different locations and different sampling times

\begin{tabular}{llllll}
\hline Sampling time & & & & & \\
\hline Coupon locations & 1 week & 2 weeks & 3 weeks & 5 weeks & 9 weeks \\
\hline Guide of cooker \# 1 & $1.0 \times 10^{1}$ & $3.0 \times 10^{1}$ & $2.3 \times 10^{5}$ & $1.7 \times 10^{5}$ & $6.3 \times 10^{3}$ \\
Guide of cooker \# 2 & $1.0 \times 10^{1}$ & $<10$ & $8.4 \times 10^{2}$ & $<10$ & $1.0 \times 10^{1}$ \\
Soup tank -top \# 1 & $<10$ & $1.0 \times 10^{1}$ & $1.5 \times 10^{1}$ & $1.3 \times 10^{2}$ & $1.6 \times 10^{2}$ \\
Soup tank -top \# 2 & $<10$ & $<10$ & $<10$ & $1.0 \times 10^{1}$ & $6.0 \times 10^{2}$ \\
Soup tank -bottom\# 1 & $<10$ & $<10$ & $5.0 \times 10^{1}$ & $<10$ & $2.0 \times 10^{2}$ \\
Soup tank- bottom \# 2 & $<10$ & $<10$ & $3.1 \times 10^{5}$ & $<10$ & $8.8 \times 10^{3}$ \\
Trolley \# 1 & $6.4 \times 10^{4}$ & $4.4 \times 10^{3}$ & $4.0 \times 10^{5}$ & $8.2 \times 10^{6}$ & $6.0 \times 10^{3}$ \\
Trolley \# 2 & $6.8 \times 10^{3}$ & $<10$ & $1.3 \times 10^{3}$ & $5.5 \times 10^{3}$ & $1.6 \times 10^{4}$ \\
Soup filling table \# 1 & $<10$ & $<10$ & $3.6 \times 10^{5}$ & $1.8 \times 10^{4}$ & $<10$ \\
Soup filling table\# 2 & $<10$ & $8.5 \times 10^{1}$ & $1.0 \times 10^{4}$ & $3.1 \times 10^{3}$ & $<10$ \\
Blue conveyor \# 1 & $7.9 \times 10^{2}$ & $3.3 \times 10^{5}$ & $<10$ & $<10$ & $<10$ \\
Blue conveyor \# 2 & $4.5 \times 10^{1}$ & $<10$ & $<10$ & $2.5 \times 10^{1}$ & $2.0 \times 10^{1}$ \\
White conveyor \# 1 & $<10$ & $<10$ & $1.7 \times 10^{4}$ & $<10$ & $<10$ \\
White conveyor \# 2 & $<10$ & $<10$ & $<10$ & $1.6 \times 10^{3}$ & $<10$ \\
\hline
\end{tabular}

Table 2. Population of Pseudomonas spp. $\left(\mathrm{CFU} / \mathrm{cm}^{2}\right)$ at different locations and different sampling times.

\begin{tabular}{llllll}
\hline Sampling times & & & & & \\
\hline Locations & 1 week & 2 weeks & 3 weeks & 5 weeks & 9 weeks \\
\hline Guide of cooker \# 1 & $<10$ & $<10$ & $1.4 \times 10^{2}$ & $4.0 \times 10^{3}$ & $5.7 \times 10^{2}$ \\
Guide of cooker \# 2 & $<10$ & $<10$ & $3.6 \times 10^{2}$ & $<10$ & $<10$ \\
Soup tank -top \# 1 & $<10$ & $<10$ & $<10$ & $<10$ & $<10$ \\
Soup tank -top \# 2 & $<10$ & $<10$ & $<10$ & $<10$ & $9.5 \times 10^{1}$ \\
Soup tank bottom\# 1 & $<10$ & $<10$ & $6.0 \times 10^{1}$ & $<10$ & $1.5 \times 10^{1}$ \\
Soup tank- bottom \# 2 & $<10$ & $<10$ & $1.5 \times 10^{5}$ & $<10$ & $4.1 \times 10^{3}$ \\
Trolley \# 1 & $2.1 \times 10^{3}$ & $3.4 \times 10^{3}$ & $1.9 \times 10^{5}$ & $2.3 \times 10^{6}$ & $1.0 \times 10^{3}$ \\
Trolley \# 2 & $2.0 \times 10^{2}$ & $<10$ & $3.5 \times 10^{2}$ & $4.3 \times 10^{3}$ & $7.3 \times 10^{3}$ \\
Soup filling table \# 1 & $<10$ & $<10$ & $2.1 \times 10^{5}$ & $6.8 \times 10^{3}$ & $<10$ \\
Soup filling table\# 2 & $<10$ & $<10$ & $2.4 \times 10^{3}$ & $6.0 \times 10^{2}$ & $<10$ \\
Blue conveyor \# 1 & $3.0 \times 10^{1}$ & $1.6 \times 10^{5}$ & $<10$ & $<10$ & $<10$ \\
Blue conveyor \# 2 & $<10$ & $<10$ & $<10$ & $1.5 \times 10^{1}$ & $<10$ \\
White conveyor \# 1 & $<10$ & $<10$ & $1.3 \times 10^{4}$ & $<10$ & $<10$ \\
White conveyor \# 2 & $<10$ & $<10$ & $<10$ & $1.3 \times 10^{3}$ & $<10$ \\
\hline
\end{tabular}

Similar to the result of TVC, large population of Pseudomonas spp. (Table 2) were found on the surface of SS coupons at trolley \#1, soup tank (bottom) and soup filling table as an evident to support the biofilm formation. Pseudomonas has been found to adhere easily to the surfaces and is excellent biofilm formers as reported in several studies $[28,29]$.

\section{Conclusions}

The present study results demonstrated that the processing equipments of food industries harbor a microbial ecosystem after production and daily cleaning procedure. Population of microflora adhesion on stainless steel coupon at food processing plant revealed that inappropriate cleaning process leads to the formation of mature biofilms after 3 weeks. Therefore, to prevent the detached or dispersed microorganism from biofilm in processing environment, effective the cleaning procedure should be developed and extensive cleaning of equipment should be done in every two weeks to inhibit biofilm formation. Moreover, extensive cleaning should be done at locations that come in contact with high nutrient content. 


\section{Acknowledgements}

The authors are grateful for financial support from the Faculty of Agro-Industry, Kasetsart University, Thailand (through the Scholarships for International Graduate Students 2012) and Agri-Biotech and Fisheries project, Vietnamese Government grant for this study.

\section{References}

[1] Bagge-Ravn, D. (2003). The microbial ecology of processing equipment in different fish industries-analysis of the microflora during processing and following cleaning and disinfection. International Journal of Food Microbiology, 87(3), 239-250.

[2] Bower, C. K., McGuire, J., \& Daeschel, M. A. (1996). The adhesion and detachment of bacteria and spores on foodcontact surfaces. Trends in Food Science \& Technology, $7(152-157)$

[3] Chmielewski, R. A. N., \& Frank, J. F. (2003). Biofilm Formation and Control in Food Processing Facilities. Comprehensive Reviews in Food Science and Food Safety, 2, 22-32.

[4] Giaouris, E., Heir, E., Hebraud, M., Chorianopoulos, N., Langsrud, S., Moretro, T., Habimana, O., Desvaux, M., Renier, S., \& Nychas, G. J. (2014). Attachment and biofilm formation by foodborne bacteria in meat processing environments: Causes, implications, role of bacterial interactions and control by alternative novel methods. Meat Sci., 97, 298-309.

[5] Zottola, E. A., \& Sasahara, K. C. (1994). Microbial biofilms in the food processing industry - Should they be a concern? International Journal of Food Microbiology, 23 125-148.

[6] Jeong, D. K., \& Frank, J. F. (1994). Growth of Listeria monocytogenes at $210 \mathrm{C}$ in Biofilms with micro-organisms Isolated from Meat and Dairy Processing Environments. $L W T$ Food Science and Technology, 27(415-424).

[7] Lavilla, L., L., Benomar, N., Galvez, A., \& Abriouel, H. (2013). Prevalence of bacteria resistant to antibiotics and/or biocides on meat processing plant surfaces throughout meat chain production. International Journal of Food Microbiology, 161(2), 97-106.

[8] Mah, T.-F. C., \& O'Toole, G. A. (2001). Mechanisms of biofilm resistance to antimicrobial agents in Microbiology. Trends in Microbiology, 9(1), 34-39.

[9] Branda, S. S., Vik, S., Friedman, L., \& Kolter, R. (2005). Biofilms: the matrix revisited. Trends in Microbiology, 13(1), 20-26.

[10] Donlan, R. M. (2002). Biofilms: Microbial Life on Surfaces. Emerging Infectious Diseases PERSPECTIVE, 8( 9), 881-890.

[11] Giaouris, E., Chorianopoulos, N., Skandamis, P., \& Nychas, G.-J. (2012). Attachment and Biofilm Formation by Salmonella in Food Processing Environments In B. S. M. Mahmoud (Ed.), Salmonella - A Dangerous Foodborne Pathogen (pp. 450). Croatia: InTech.

[12] Khamisse, E., Firmesse, O., Christieans, S., Chassaing, D., \& Carpentier, B. (2012). Impact of cleaning and disinfection on the non-culturable and culturable bacterial loads of foodcontact surfaces at a beef processing plant. International Journal of Food Microbiology, 158(2), 163-168.

[13] van der Veen, S., \& Abee, T. (2011). Mixed species biofilms of Listeria monocytogenes and Lactobacillus plantarum show enhanced resistance to benzalkonium chloride and peracetic acid. International Journal of Food Microbiology, 144(3), 421-431.

[14] Costerton, J. W., Stewart, P. S., \& Greenberg, E. P. (1999). Bacterial Biofilms: A Common Cause of Persistent Infections. Science, 284(5418), 1318-1322.

[15] Eileen, B. S., \& Amy, C. L. W. (2004). Efficacy of Two Cleaning and Sanitizing Combinations on Listeria monocytogenes Biofilms Formed at Low Temperature on a Variety of Materials in the Presence of Ready-to-Eat Meat Residue. Journal of Food Protection, 67(10), 2218-2229.

[16] Kumar, C. G., \& Anand, S. K. (1998). Significance of microbial biofilms in food industry: a review. International Journal of Food Microbiology, 42, 9-27.

[17] Arciola, C. R., Campoccia, D., Speziale, P., Montanaro, L., \& Costerton, J. W. (2012). Biofilm formation in Staphylococcus implant infections. A review of molecular mechanisms and implications for biofilm-resistant materials. Biomaterials, 33(26), 5967-5982.

[18] Pan, Y., Breidt, F. J., \& Kathariou, S. (2006). Resistance of Listeria monocytogenes biofilms to sanitizing agents in a simulated food processing environment. Applied and Environmental Microbiology, 72(12), 7711-7717.

[19] Poimenidou, S., Belessi, C. A., Giaouris, E. D., Gounadaki, A. S., Nychas, G. J., \& Skandamis, P. N. (2009). Listeria monocytogenes attachment to and detachment from stainless steel surfaces in a simulated dairy processing environment. Applied and Environmental Microbiology, 75(22), 7182-7188.

[20] Rodrigues, D. A. F. (2010). Listeria monocytogenes and Salmonella enterica adhesion, biofilm formation and control. Universidade do Minho, Escola de Engenharia.

[21] Sauer, K. C., A. K. Ehrlich, G. D. Costerton, J. W. Davies, D. G. (2002). Pseudomonas aeruginosa Displays Multiple Phenotypes during Development as a Biofilm. Journal of Bacteriology, 184(4), 1140-1154.

[22] Yang, L., Liu, Y., Wu, H., Hoiby, N., Molin, S., \& Song, Z. J. (2011). Current understanding of multi-species biofilms. Int $J$ Oral Sci, 3(2), 74-81.

[23] Dourou, D., Beauchamp, C. S., Yoon, Y., Geornaras, I., Belk, K. E., Smith, G. C., Nychas, G. J., \& Sofos, J. N. (2011). Attachment and biofilm formation by Escherichia coli O157:H7 at different temperatures, on various food-contact surfaces encountered in beef processing. International Journal of Food Microbiology, 149(3), 262-268.

[24] Fuster-Valls, N., Hernández-Herrero, M., Marín-de-Mateo, M., \& Rodríguez-Jerez, J. J. (2008). Effect of different environmental conditions on the bacteria survival on stainless steel surfaces. Food Control, 19(3), 308-314.

[25] Helke, D., Somers, E., \& Wong, A. (1993). Attachment of Listeria monocytogenes and Salmonella typhimurium to stainless steel and Buna- $\mathrm{N}$ in the presence of milk and individual milk components. Journal of food protection (USA). 
[26] Birna, G., Einarsson, H., \& Thorkelsson, G. (2005). Microbial Adhesion to Processing Lines for Fish Fillets and Cooked Shrimp: Influence of Stainless Steel Surface Finish and Presence of Gram-Negative Bacteria on the Attachment of Listeria monocytogenes. Food Technology and Biotechnology, 43(1), 55-61.

[27] Gunduz, G. T., \& Tuncel, G. (2006). Biofilm formation in an ice cream plant. Antonie Van Leeuwenhoek, 89(3-4), 329-336.
[28] Hood, S. K., \& Zottola, E. A. (1997). Isolation and Identification of Adherent Gram-Negative Microorganisms from Four Meat-Processing Facilities. Journal of Food Protection, 60(9), 1135-1138.

[29] Marchand, S., Block, D. J., Jonghe, D. V., Coorevits, A., Heyndrickx, M., \& Lieve, H. (2012). Biofilm Formation in Milk Production and Processing Environments; Influence on Milk Quality and Safety. Comprehensive Reviews in Food Science and Food Safety, 11(2), 133-147. 